\title{
Effect of concrete cover thickness and main reinforcement ratio on flexural behavior of RC beams strengthened by NSM-GFRP bars
}

\author{
Hesham EL-Emam \\ Zagarig University, Egypt \\ elemamb@mail.missouri.edu, bttp:/ / orcid.org/0000-0002-7685-2985
}

\author{
Alaa El-Sisi \\ University of Missouri, USA \\ aep64@mail.missouri.edu, bttp:/ / orcid.org/0000-0001-8190-6100
}

\author{
Ramy Reda \\ Higher Technological Institute, Egypt \\ ramy_mostafa12000@yahoo.com,bttp://orcid.org/0000-0002-3298-7925
}

\author{
Mohamed Seleem, Mohamed Bneni \\ Zagarig University, Egypt \\ mbseleem1963@gmail.com, bttp:/ / orcid.org/0000-0002-5777-4651 \\ mobamedbneni@yahoo.com, http://orcid.org/0000-0002-4352-5654
}

\begin{abstract}
Experimental and numerical programs were conducted to investigate the effect of concrete cover and area of main steel reinforcement on the flexural behavior of strengthened RC beams by near-surface mounted glass fiber reinforced polymeric (NSM GFRP) bars of different lengths. Nine beams divided into three main groups were tested under four-point bending. The three beams of the first group were strengthened by different lengths of GFRP bars and having a concrete cover of $50 \mathrm{~mm}$, while the three beams in the second group were strengthened in a similar manner as those of the first group but the concrete cover was $30 \mathrm{~mm}$. The main steel reinforcement in the first and second groups was $2 \varnothing 10$. The three beams of the third group were similar to those of the first and second group but the main steel reinforcement was 2Ø16. The 3-D FE commercial ANSYS program was used for the numerical work. The experimental results showed that decreasing the concrete cover increased the flexural capacity of the strengthened RC beams but this improvement disappeared by decreasing the NSM GFRP bar length. The numerical results showed an agreement with the experimental results.
\end{abstract}

KEYwORDS. Near Surface Mounted; Flexural Strengthening; Concrete Cover Separation; FE models.

\section{OPEN ACCESS}

Citation: EL-Emam, H., El-Sisi, A., Reda, R., Seleem, M., Bneni., M., Effect of concrete cover thickness and main reinforcement ratio on flexural behavior of RC beams strengthened by NSM-GFRP bars, Frattura ed Integrità Strutturale, 52 (2020) 197-212.

Received: 05.01 .2020

Accepted: 11.02.2020

Published: 01.04.2020

Copyright: (C) 2020 This is an open access article under the terms of the CC-BY 4.0, which permits unrestricted use, distribution, and reproduction in any medium, provided the original author and source are credited. 


\section{INTRODUCTION}

he NSM is used in many countries for repairing and strengthening of structural members. The NSM technique is recognized as a promising method for increasing the load-carrying capacity of RC beams. The implementation process is divided into two main stages: the first stage is cutting grooves into the concrete cover of reinforced concrete elements. The second stage is the inserting of FRP rods into these grooves and bonding by an epoxy resin. The NSM technique is a very promising method for the rehabilitation of RC members. Many researchers have introduced the advantages of the NSM technique over the conventional methods [1-5]. Firstly, the NSM bars are protect by the concrete cover, thus they are less exposed to accidental damage such as fire, in comparison to bonded FRP plates. Secondly, the use of NSM is less time consuming and requires less efforts than many other techniques such as concrete jacketing or steel reinforcements.

Over the last twenty years, a great deal of research was deployed to the behavior and flexural strength of RC members strengthened by NSM FRP rods. Previous studies focuses on many aspects of the behavior of RC beams strengthened NSM GFRP rods such as ultimate flexural and shear capacities, ultimate deflection and the failure modes [6-15]. Furthermore, A lot of laboratory experimental works were carried out to explore the bonding behavior between NSM FRP bars and concrete, the effect of FRP anchorage system, NSM FRP length, type of epoxy, dimensions of grooves, size, shape, and type of rebars and concrete strength [16-21]. Lot of studies have worked to increase the bonding capacity in order to increase both the flexural and shear capacity of the strengthened RC beams. On the other hand, other works $[22-25,29]$ used the finite element method [FE] in predicting the measured experimental results. Three-dimensional (3D) nonlinear FE model was developed for simulating the flexural behavior of RC beams strengthened by NSM technique systems. The numerical results obtained from these studies reflected the performance of NSM-FRP bars when used as internal reinforcement against flexure in RC beams.

This paper presents the results of an experimental and numerical study on flexural behavior of strengthened RC beams by glass fiber reinforced polymer (GFRP) rods. The study aimed to reduce the concrete cover from $50 \mathrm{~mm}$ to $30 \mathrm{~mm}$ while varying the steel reinforcement ratio and using different lengths of GFRP bars.

\section{EXPERIMENTAL PROGRAM}

\section{Specimens Geometry and Reinforcement}

7 he reinforced concrete beams were designed according to ACI 318 (2011)[26 ]. The cross-sectional dimensions of the specimens were $200 \mathrm{~mm} \times 300 \mathrm{~mm}$. The total length of the beams was $2300 \mathrm{~mm}$ and the loaded span was $2200 \mathrm{~mm}$. The main steel reinforcement consisted of $2 \varnothing 10 \mathrm{~mm}$ bars or $2 \varnothing 16 \mathrm{~mm}$ depends on the type of test group with $2 \varnothing 8 \mathrm{~mm}$ bars as compression steel reinforcement as shown in (Fig. 1). The shear reinforcement consisted of 8 $\mathrm{mm}$ stirrups spaced $100 \mathrm{~mm}$ center to center throughout the beam span. After 28 days of curing time, the first stage of preparation was undertaken, i.e. cutting grooves into the concrete cover with $25 \mathrm{~mm}$, and $30 \mathrm{~mm}$ in depth and width, respectively. The second stage were installing the GFRP rods in the grooves using epoxy. The specimens were kept for at least 7 days for the curing of epoxy before testing.

\section{Experimental Matrix}

A total of nine RC beams were tested. The nine beams were divided into three groups depending on the variable parameters studied. Each group consisted of three beams reinforced respectively with GFRP bars of lengths $550 \mathrm{~mm}$, $1150 \mathrm{~mm}, 1800 \mathrm{~mm}$. In Group A, the three beams have $2-\varnothing 10 \mathrm{~mm}$ as a main reinforcement and the beams concrete

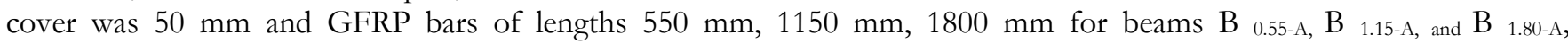
respectively. In Group B the main reinforcement was $2-\varnothing 10 \mathrm{~mm}$ and the concrete cover was reduced to be $30 \mathrm{~mm}$ with

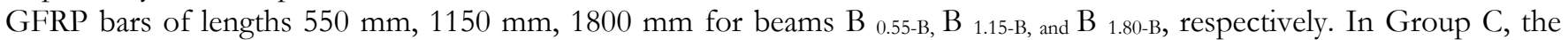
main reinforcement was increased to $2-\varnothing 16 \mathrm{~mm}$ and the concrete cover was $30 \mathrm{~mm}$ as group B with GFRP bars of lengths $550 \mathrm{~mm}, 1150 \mathrm{~mm}, 1800 \mathrm{~mm}$ for beams $\mathrm{B}_{0.55-\mathrm{C},} \mathrm{B}_{1.15-\mathrm{C} \text {, and }} \mathrm{B}_{1.80-\mathrm{C}}$, respectively . Further details of the tested beams are presented in Tab. 1.

\section{Material Properties}

The specimens were cast from one batch using the same concrete mix design ratios. The casting was done using Type I ordinary portland cement (Cem $42.5 \mathrm{~N})$. The coarse aggregates were dolomite of $20 \mathrm{~mm}$ maximum aggregate size. Natural 
sand was used as a fine aggregate. Clean tap drinking water was used for mixing and curing of all beams. The mix design for one cubic meter was, water/cement of 0.45 , water contents of $180 \mathrm{~kg}$., sand content equals $635 \mathrm{~kg}$, dolomite content equals $1155 \mathrm{~kg}$. and Superplasticizer dosage equals $4.0 \mathrm{~kg}$.
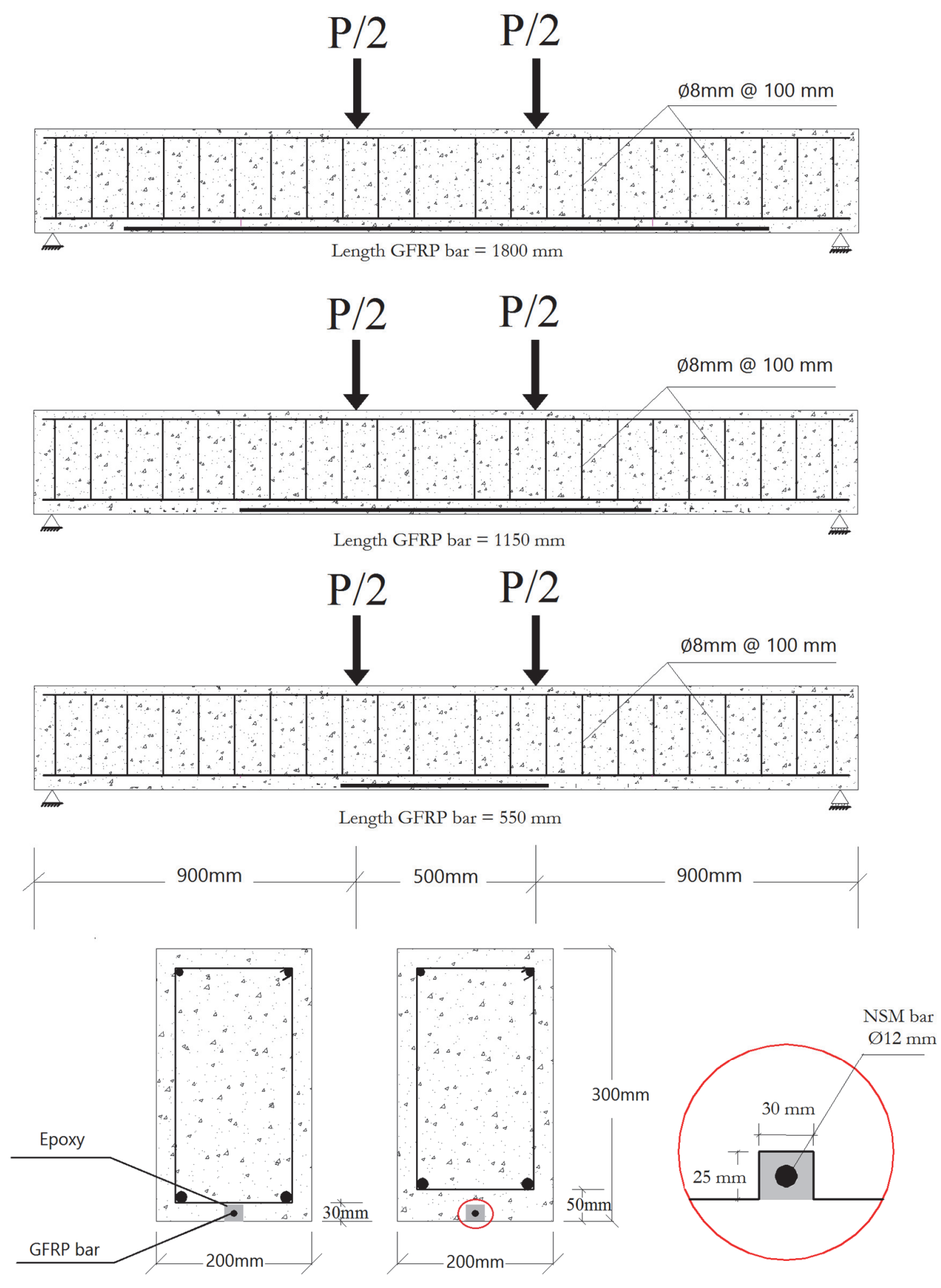

$\mathrm{Cc}=30 \mathrm{~mm}$

$\mathrm{Cc}=50 \mathrm{~mm}$

Figure 1: Specimens design details 
Based on tests of three $150 \mathrm{~mm}$ x $150 \mathrm{~mm}$ x $150 \mathrm{~mm}$ concrete cubes, The 28-day average compressive strength of the concrete was $35 \mathrm{MPa}$, while spitting tensile strength was $2.95 \mathrm{MPa}$ based on tests of three $150 \mathrm{~mm}$ x $300 \mathrm{~mm}$ concrete cylinders. The yield and ultimate strength of $\varphi 8, \varphi 10$, and $\varphi 16 \mathrm{~mm}$ steel bars were $480 \mathrm{MPa}$ and $590 \mathrm{MPa}$ respectively. The modulus of elasticity for all bars was $200 \mathrm{GPa}$. The GFRP bars made in (Haining Anjie Composite Material Co., Ltd., Haining, China) of $\varnothing 12 \mathrm{~mm}$ diameter for strengthening in this research. The GFRP tensile strength and modulus of elasticity were $750 \mathrm{MPa}$ and $56 \mathrm{GPa}$ respectively. The MASTERBRACE SAT 4500 (BASF) type epoxy was used to bond the NSM GFRP bars to the concrete grooves.

\begin{tabular}{|c|c|c|c|c|}
\hline Type of Series & Sample ID & Length of GFRP & Main steel & Concrete cover \\
\hline \multirow{3}{*}{ Group - A } & $\mathrm{B}_{1.80-\mathrm{A}}$ & $1800 \mathrm{~mm}$ & \multirow{3}{*}{$2-\varnothing 10 \mathrm{~mm}$} & \multirow{3}{*}{$50 \mathrm{~mm}$} \\
\hline & $\mathrm{B}_{1.15-\mathrm{A}}$ & $1150 \mathrm{~mm}$ & & \\
\hline & $\mathrm{B}_{0.55-\mathrm{A}}$ & $550 \mathrm{~mm}$ & & \\
\hline \multirow{3}{*}{ Group - B } & $\mathrm{B}_{1.80-\mathrm{B}}$ & $1800 \mathrm{~mm}$ & \multirow{3}{*}{$2-\varnothing 10 \mathrm{~mm}$} & \multirow{3}{*}{$30 \mathrm{~mm}$} \\
\hline & $\mathrm{B}_{1.15-\mathrm{B}}$ & $1150 \mathrm{~mm}$ & & \\
\hline & $\mathrm{B}_{0.55-\mathrm{B}}$ & $550 \mathrm{~mm}$ & & \\
\hline \multirow{3}{*}{ Group - C } & $\mathrm{B}_{1.80-\mathrm{C}}$ & $1800 \mathrm{~mm}$ & \multirow{3}{*}{ 2-Ø16mm } & \multirow{3}{*}{$30 \mathrm{~mm}$} \\
\hline & $\mathrm{B}_{1.15-\mathrm{C}}$ & $1150 \mathrm{~mm}$ & & \\
\hline & $\mathrm{B}_{0.55-\mathrm{C}}$ & $550 \mathrm{~mm}$ & & \\
\hline
\end{tabular}

Table 1: Test matrix.

\section{Instrumentation and test set up}

All beams tested under four points bending using a universal testing machine of $1000 \mathrm{kN}$ maximum capacity as shown in (Fig. 2-a). A solid steel spreader beam was used to apply the load to the RC strengthened beams. A load cell was mounted between the machine and the rigid beam as shown in (Fig. 2-a). Moreover, LVDT was used to measure the deflection at the beam mid-span. Strain gages were used to measure the strains at the main reinforcing steel and NSM-GFRP rods by bonding it to the middle of bars. The data logger system was used to collect the data as shown in (Fig. 2-b).

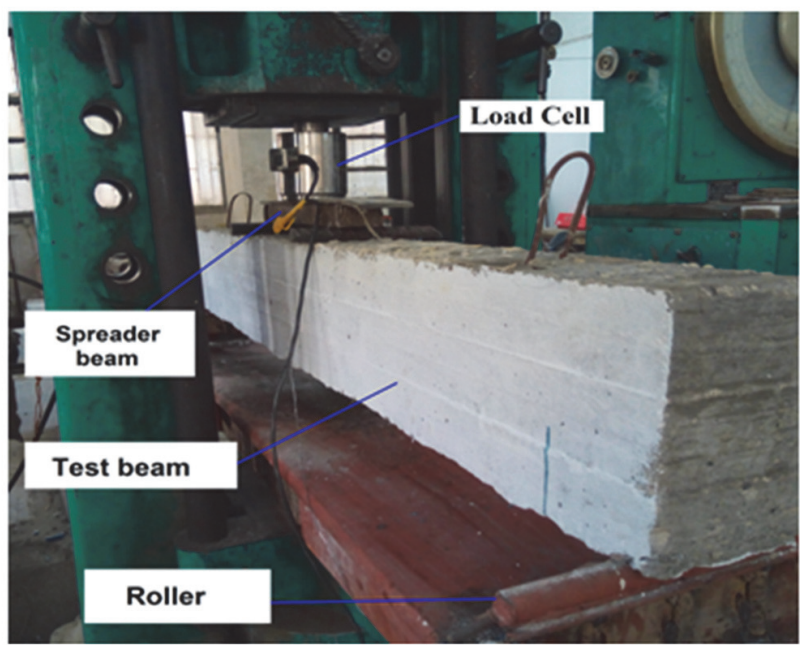

(a)

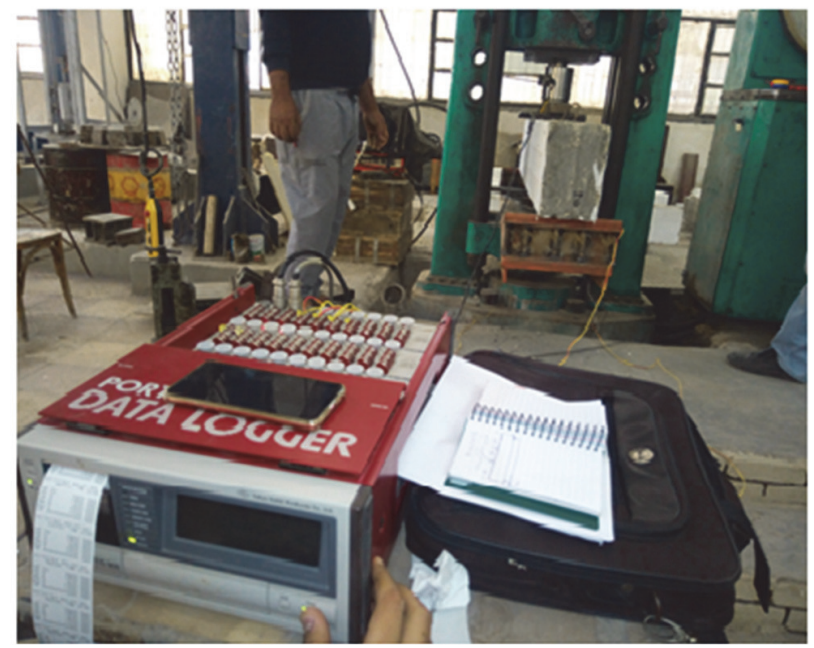

(b)

Figure 2: Flexural test setup and data logger 


\section{RESULTS AND DISCUSSION}

he experimental results of the nine tested beams will be analyzed and discussed in the following sections. The effect of changing the depth of concrete cover from $50 \mathrm{~mm}$ to $30 \mathrm{~mm}$ on the efficiency of strengthening by NSM rods of different lengths will be mentioned. This is followed by analyzing the effect of main steel reinforcement on the flexural behavior of the strengthened RC beams by different lengths of NSM GFRP rods.

\section{Effect of Concrete cover depth on Load - Deflection Curve}

The effect of concrete cover depth on load-deflection behavior of strengthened RC beams by different lengths of NSM GFRP rods is shown in (Fig. 3). The solid line in the curves represents beams having a concrete cover of $50 \mathrm{~mm}$ while the dashed line is for the concrete cover of $30 \mathrm{~mm}$. The ultimate loads for beams with $30 \mathrm{~mm}$ concrete cover thickness $\mathrm{B}_{1.80-\mathrm{B} \text {, }}$ $\mathrm{B}_{1.15-\mathrm{B}}$ and $\mathrm{B}_{0.55-\mathrm{B}}$ increased by $13.4 \%, 5.56 \%$ and $9.0 \%$, compared to beams with $50 \mathrm{~mm}$ concrete cover thickness $\mathrm{B}_{1.80-\mathrm{A}}$, $\mathrm{B}_{1.15-\mathrm{A}}$ and $\mathrm{B}_{0.55-\mathrm{A}}$, respectively. The results showed an improvement in the flexural capacity value of the strengthened RC beams with a $30 \mathrm{~mm}$ concrete cover compared to RC beams with a $50 \mathrm{~mm}$ concrete cover. This improvement reduced by decreasing the NSM GFRP bar length as shown in (Fig.3). It was also observed that, the improvement in the ultimate load of the strengthened RC beams of concrete cover $30 \mathrm{~mm}$ was very clear in the case of beam $\mathrm{B}_{1.80}$.

\section{Strain distribution on Main Steel Reinforcement and GFRP bars with alteration of Concrete cover.}

Fig. 4 shows the effect of concrete cover on the load - main steel strain behavior for the strengthened beams by NSM GFRP rod of lengths $1800 \mathrm{~mm}$ and $550 \mathrm{~mm}$ (i.e. B1.80 A and b and B0.55 A and B). The strains were measured in the middle of the main steel bars in the mid-span of the tested beam. The main steel bar strains of beam $\mathrm{B}_{1.80-\mathrm{B}}$ strengthened with NSM GFRP bar of length equals $1800 \mathrm{~mm}$ with the concrete cover of 30 recorded the higher tensile strains in steel bar compared to beam $\mathrm{B}_{1.80-\mathrm{A}}$ with the concrete cover of $50 \mathrm{~mm}$. So, it could be concluded that, reducing the distance between the main steel reinforcement and NSM GFRP rods increase the efficiency of the main steel leading to higher beam capacity and strains as shown in (Fig. 5).
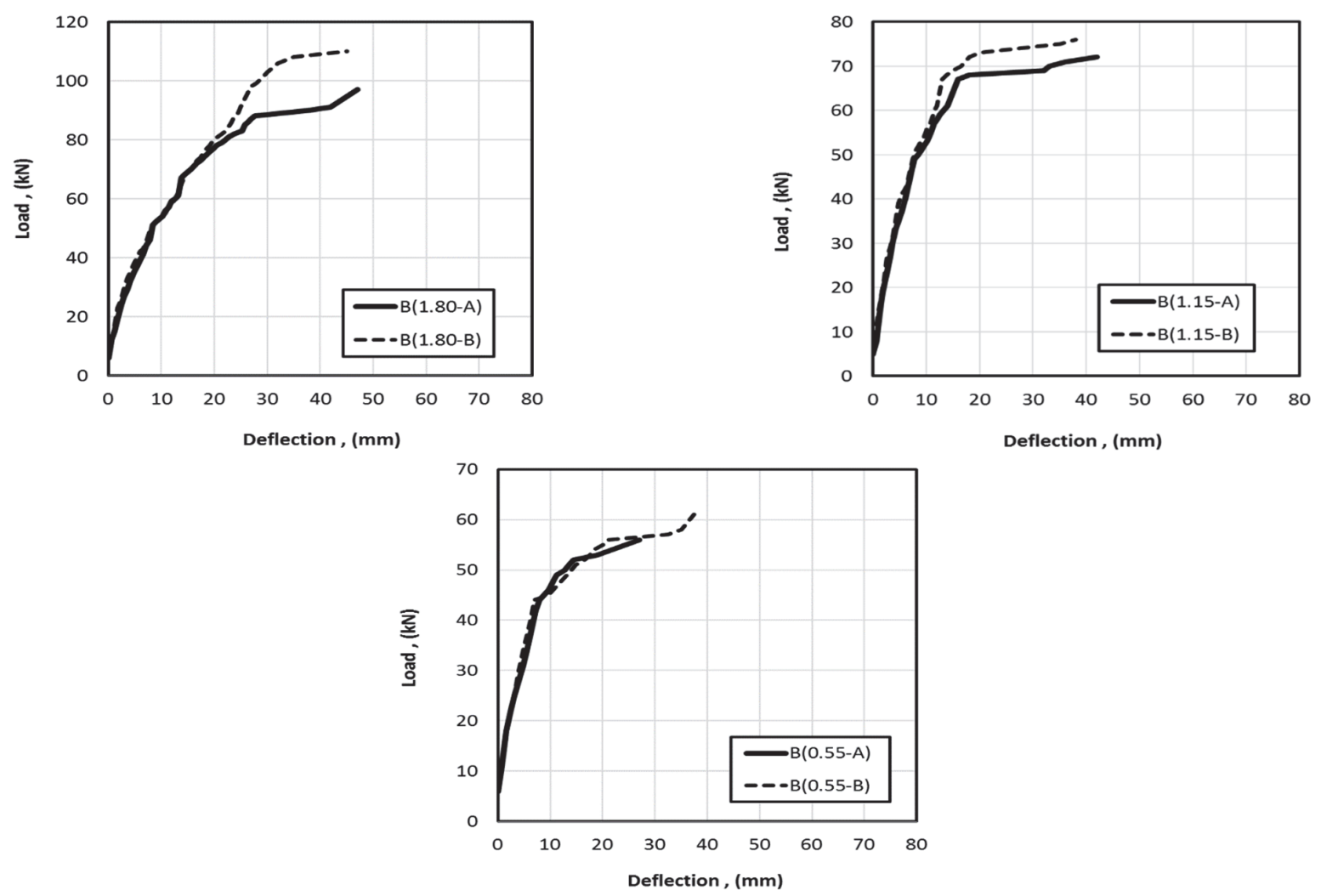

Figure 3: Effect concrete cover on load - deflection behavior at different lengths of strengthening GFRP bars 

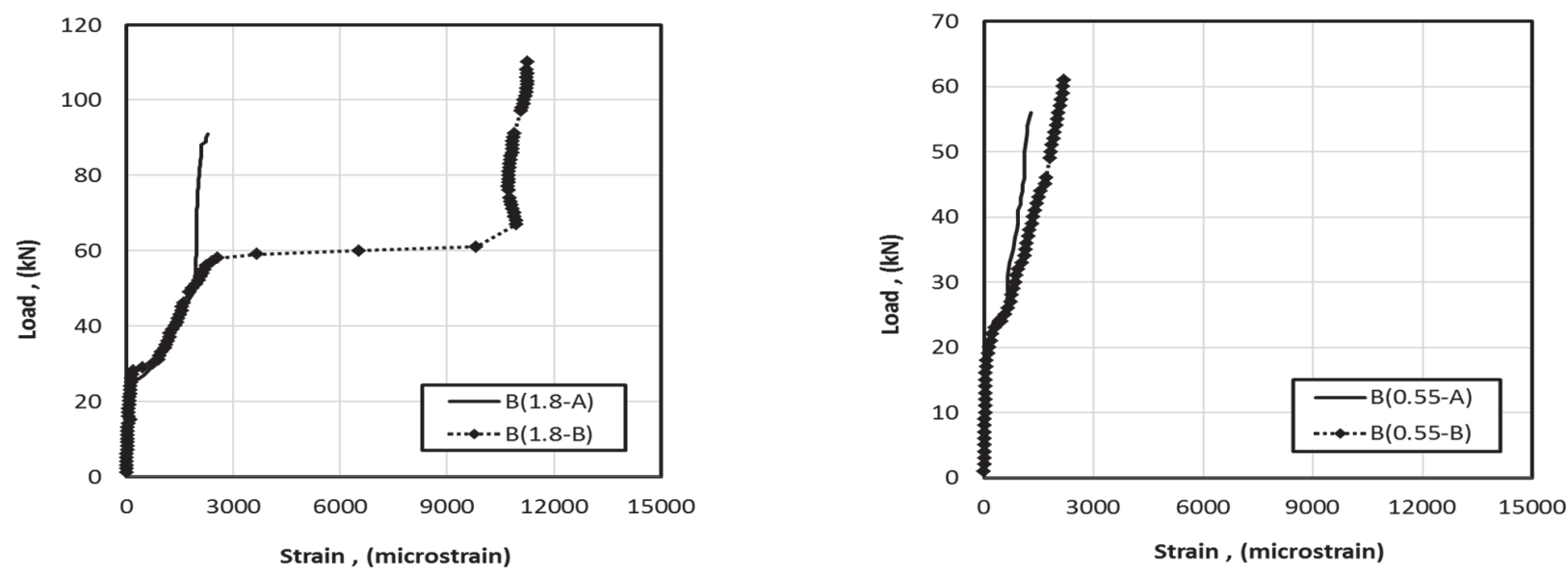

Figure 4: Effect concrete cover on strain in main reinforcements
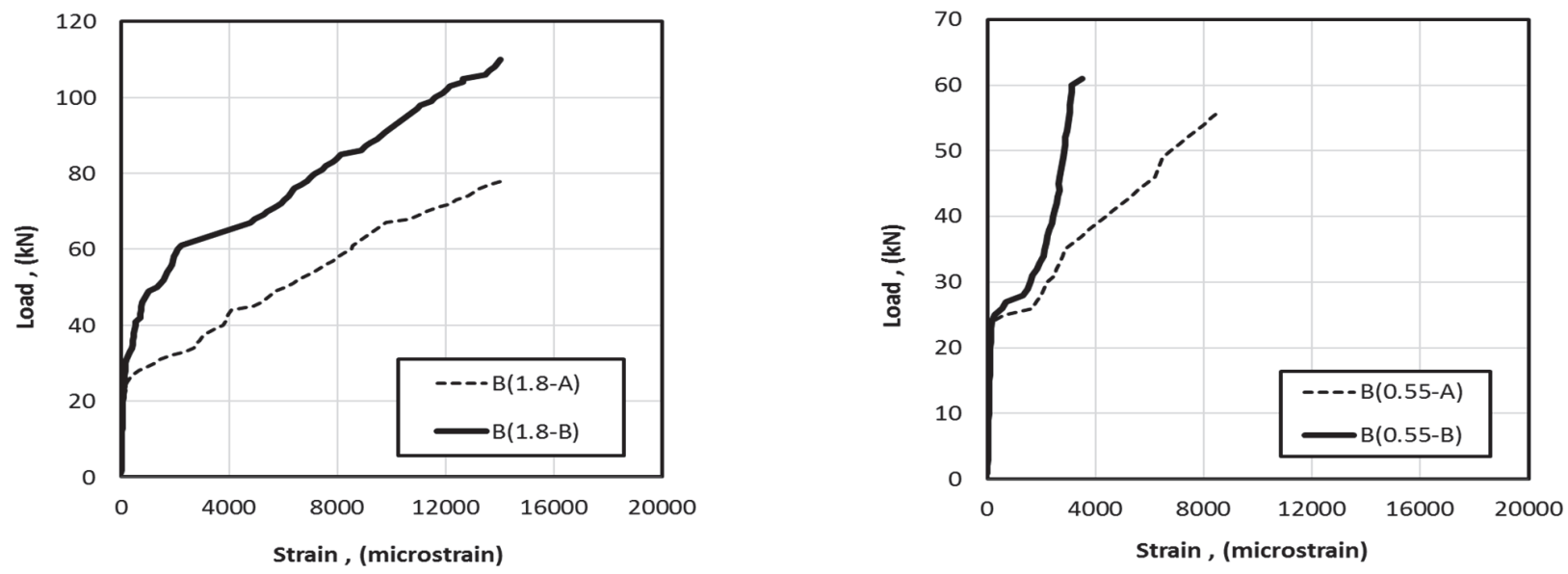

Figure 5: Effect concrete cover on strain in the middle of NSM GFRP bar

\section{Effect of steel reinforcement ratio}

Fig. 6 shows, the load-deflection curve for group b and c beams with $30 \mathrm{~mm}$ concrete cover but having different main steel reinforcement ratio. It can be seen that increasing the main steel reinforcement ratio leads to increasing the beam's ultimate loads. Besides, it reduces the efficiency of the GFRP bars as shown in Fig. (6). By increasing the main steel reinforcement from $2 \varnothing 10 \mathrm{~mm}$ to $2 \varnothing 16 \mathrm{~mm}$, the RC beam flexural strength for the B1.80, B1.15, and B0.55 with a $30 \mathrm{~mm}$ concrete cover increased by $66.66 \%, 75.7 \%$, and 133.3\%, respectively. It can be concluded that the efficiency of the NSMFRP system decreased with increasing the steel reinforcement ratio.

\section{Effect of main steel reinforcement ratio on strain distribution in NSM GFRP bars.}

The effect of the main steel reinforcement ratio on load -strain behavior in NSM GFRP bars for beams having a concrete cover of $30 \mathrm{~mm}$ and NSM GFRP bar lengths of $1800 \mathrm{~mm}$ and $550 \mathrm{~mm}$ is shown in (Fig.7). It is clear that the efficiency of the NSM-FRP system decreased with increasing the steel reinforcement ratio. So that the strain in the GFRP bars exhibited the same value with different steel ratios. It can be concluded that the steel reinforcement ratio affected the NSM-GFRP system's role in strengthening.

\section{Crack Pattern and Mode of Failure}

The failure modes of beams strengthened with NSM GFRP rods that have a concrete cover of $30 \mathrm{~mm}$ are shown in (Fig. 8) - Group B. For beam $\mathrm{B}_{1.80-\mathrm{B}}$, it is observed that the yielding of the reinforcing steel occurred firstly, then it is followed by debonding and separation of the concrete cover. Beam $\mathrm{B}_{1.15-\mathrm{B}}$ failed in a flexural mode which is yielding of the reinforcing steel followed by GFRP debonding due to stress concentration at the ends of GFRP bar. A typical mode of 
failure of under reinforced concrete beams was observed in the case of beam $\mathrm{B}_{0.55-\mathrm{B}}$, where the crack started at the critical section (end of the GFRP rod), which is near the constant moment region and then transferred to the strengthened section. Also, with increasing of bottom steel reinforcement ratio Group $\mathrm{C}$, follows the same mode of failure of beams as in Group B
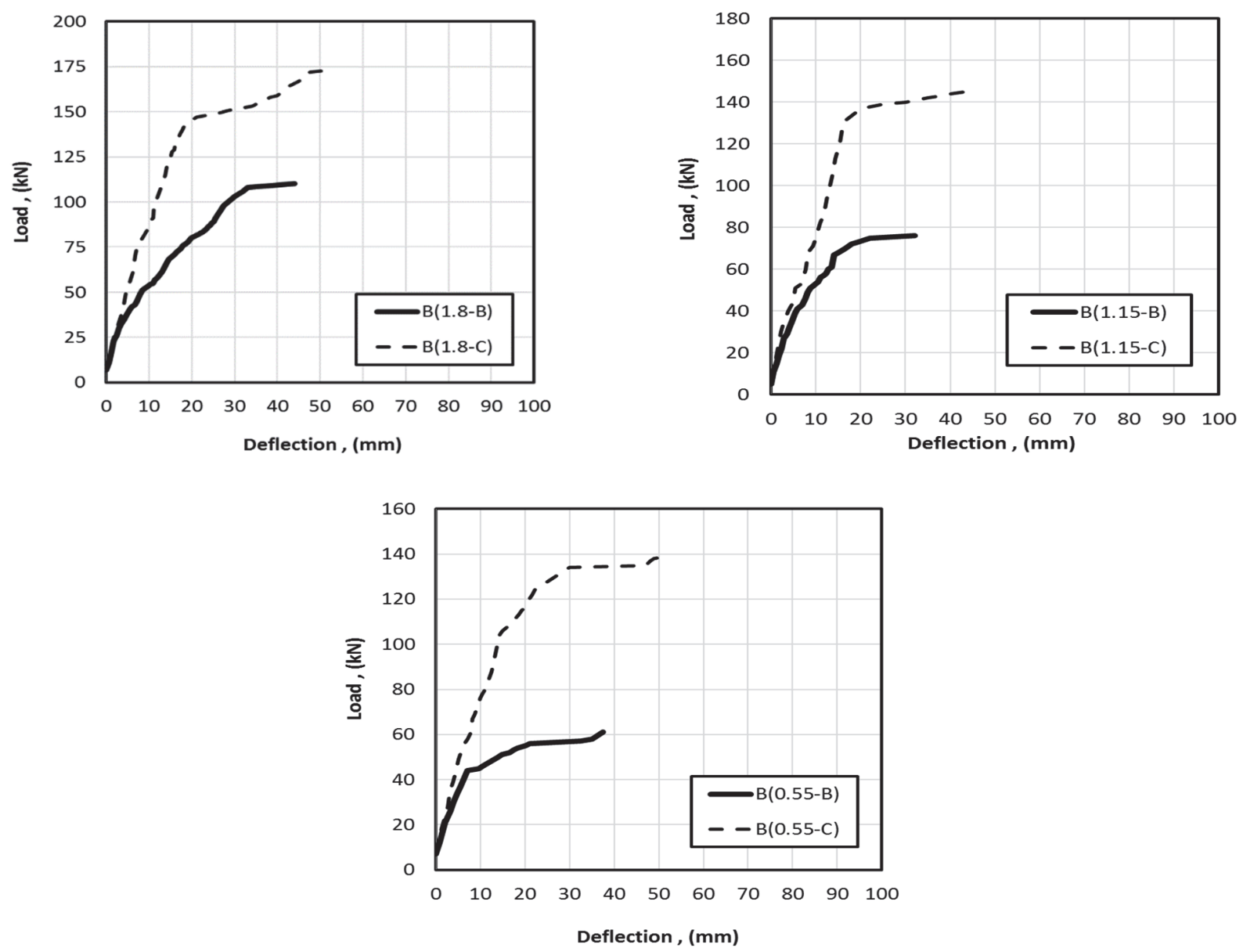

Figure 6: Load - Deflection Curve during effect of increase ratio steel
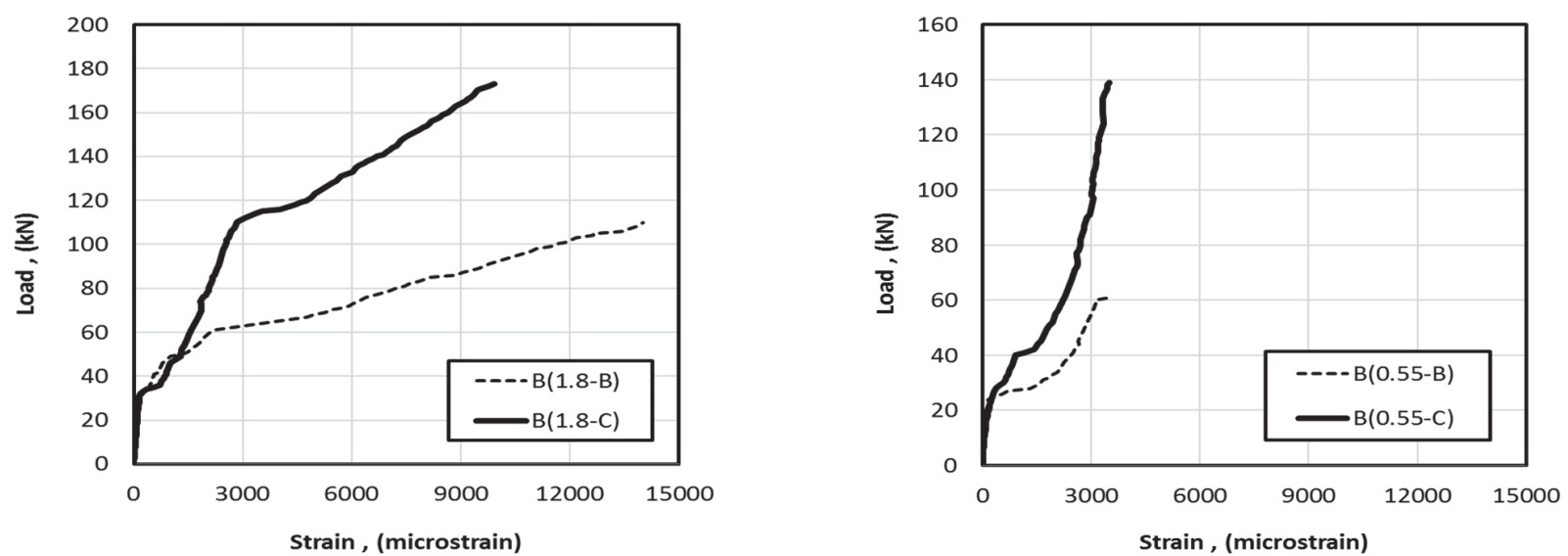

Figure 7: Strain distribution on GFRP bars during increase ratio steel reinforcement 


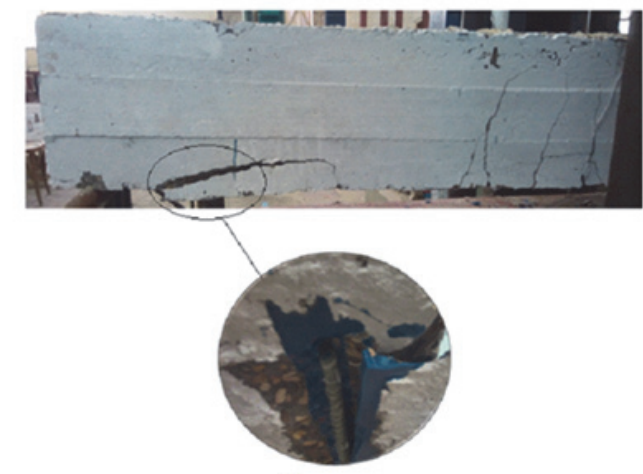

$\mathrm{B}_{1.80 \text { - B }}$

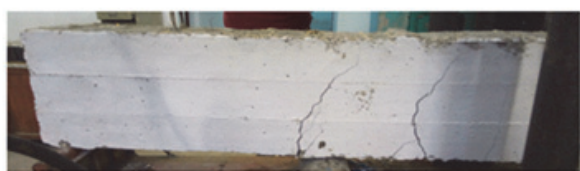

$\mathrm{B}_{1.15 \cdot \mathrm{B}}$

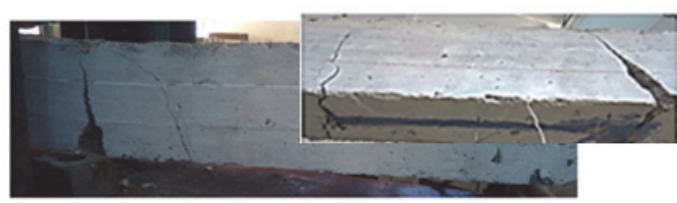

$\mathrm{B}_{0.55 \cdot \mathrm{B}}$
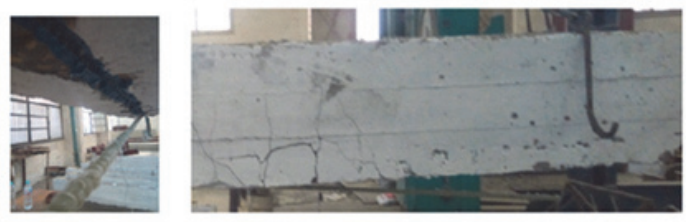

$\mathrm{B}_{1.80 \cdot \mathrm{c}}$

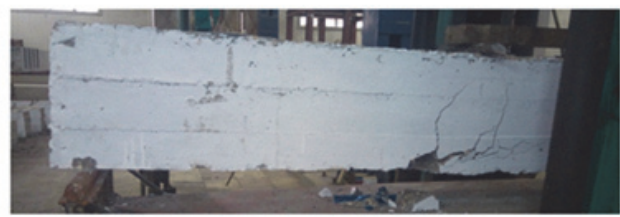

$\mathrm{B}_{1.15-\mathrm{c}}$

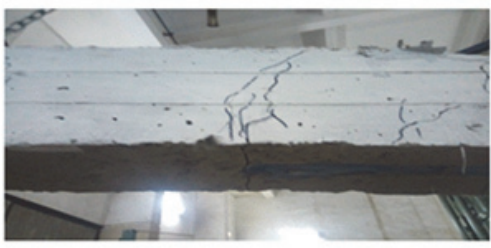

$\mathrm{B}_{0.55 \cdot \mathrm{c}}$

Figure 8: Modes of failure for Group B, C.

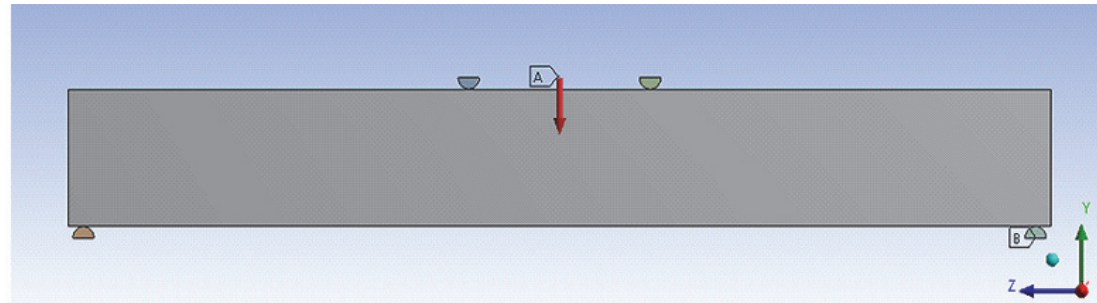

(a)
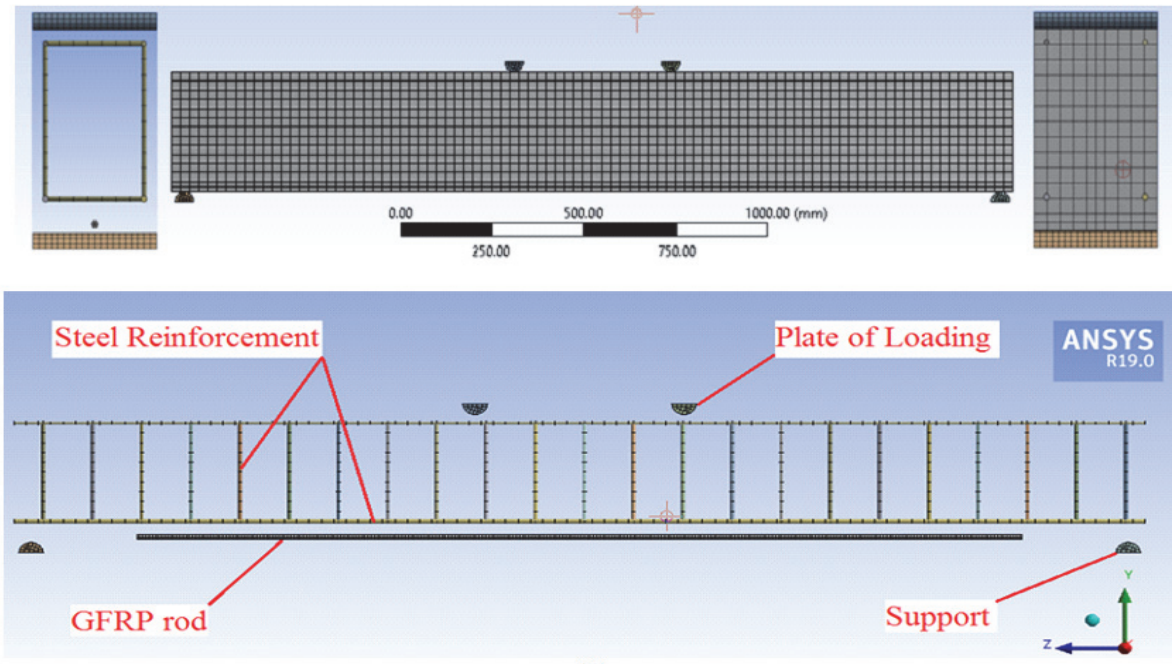

(b)

Figure 9: The Numerical Model: (a) RC beam, (b) Structural model and Meshing 
NUMERICAL MODEL

$\mathrm{T}$ he three dimensional (3-D) finite element (FE) analysis software ANSYS [28] was used for the analysis of the reinforced beams strengthened with NSM GFRP rods. Fig. 9(a) presents the modeled beam, supports and loading plates. The dimensions of the full-size beams were $2300 \mathrm{~mm} \times 200 \mathrm{~mm} \times 300 \mathrm{~mm}$ and the span between the supports was $2200 \mathrm{~mm}$, while, Fig. 9(b) shows the structural model and mesh used in this study. The element size has been adopted to be $25 \mathrm{~mm}$ based on the mesh sensitivity. Solid element (Solid 65) has been used to define the 3-D of the structural reinforced concrete. Solid 65 able to crack in tension and crush in compression. This element was simulated by 8 -nodes and three translational degrees of freedom at each node. However, the steel reinforcement was modeled using LINK 180. Furthermore, 3-D structural solid element (Solid 45) was used to model the loading plate and supports. Tab. 2 presents the mechanical properties of the materials used in the numerical modeling.

\begin{tabular}{cccc}
\hline Material & Properties & Unit & Data \\
& Compression strength & $\mathrm{MPa}$ & 31.0 \\
Concrete & Tensile strength & $\mathrm{MPa}$ & 2.0 \\
& Young's modulus, $\mathrm{E}_{\mathrm{c}}$ & $\mathrm{MPa}$ & 17500 \\
& Passion's ratio & $\mathrm{MPa}$ & 196000 \\
& Young's modulus, $\mathrm{E}_{\mathrm{s}}$ & $\mathrm{MPa}$ & 480 \\
& Yield stress, $\mathrm{f}_{\mathrm{y}}$ & & 0.2 \\
\hline \multirow{3}{*}{ Main Steel } & Passion's ratio & $\mathrm{MPa}$ & 196000 \\
& Young's modulus, $\mathrm{E}_{\mathrm{s}}$ & $\mathrm{MPa}$ & 250 \\
& Yield stress, $\mathrm{f}_{\mathrm{y}}$ & & 0.2 \\
\hline \multirow{3}{*}{ Stirrups } & Passion's ratio & $\mathrm{MPa}$ & 56000 \\
& Young's modulus & $\mathrm{MPa}$ & 750 \\
& Tensile ultimate strength & & 0.2 \\
\hline \multirow{2}{*}{ GFRP rod } & Passion's ratio & $\mathrm{MPa}$ & 3780 \\
& Young's modulus & $\mathrm{MPa}$ & 30 \\
\hline \multirow{2}{*}{ Epoxy resin } & Tensile yield strength & & 0.35 \\
& Passion's ratio & &
\end{tabular}

Table 2: Material properties used in the numerical study.

\section{COMPARISON OF EXPERIMENTAL AND NUMERICAL RESULTS}

\section{Load-Deflection Curve}

7 he load-deflection curves which obtained for Group-B and Group-C from the experimental results and the FE models are shown in (Fig. 10). It is clear that the experimental and numerical load-deflection results were in good agreement. So, the FE models demonstrated the ability to simulate the behavior of reinforced concrete beams strengthened by the NSM technique. The simulation perfectly reflected the bonding between concrete, steel reinforcement and strengthening by NSM-GFRP rods. Moreover, the FE models result in confirming to affect the flexural capacity of beams strengthened with alteration of the concrete cover. With the aid of Fig. 6, it can be concluded that the effect of increasing the amount of tensile reinforcing steel on the efficiency of strengthened beams is more pronounced in the case of short GFRP bar length.

\section{Strain distribution on along NSM GFRP bars}

Fig. 11 illustrates strains distribution along the GFRP bars by FE models compared to the strains measured experimentally. Good agreement between the experimental and predicted numerically GFRP rods are observed. 


\section{Crack patterns}

Numerical results show that the concrete cover thickness seems to have little influence on the first crack loading compared to the variation of the internal main steel. Fig. 12 shows a crack pattern of beam $\mathrm{B}_{1.15-\mathrm{A}}$ and beam $\mathrm{B}_{1.15-\mathrm{B}}$ during loading. It can be observed that the first cracking load for $\mathrm{B}_{1.15-\mathrm{B}}$ and having concrete cover equals $30 \mathrm{~mm}$ was recorded at $16 \mathrm{kN}$. While this load was $15 \mathrm{kN}$ for beam $\mathrm{B}_{1.15-\mathrm{A}}$ having concrete cover equals $50 \mathrm{~mm}$.

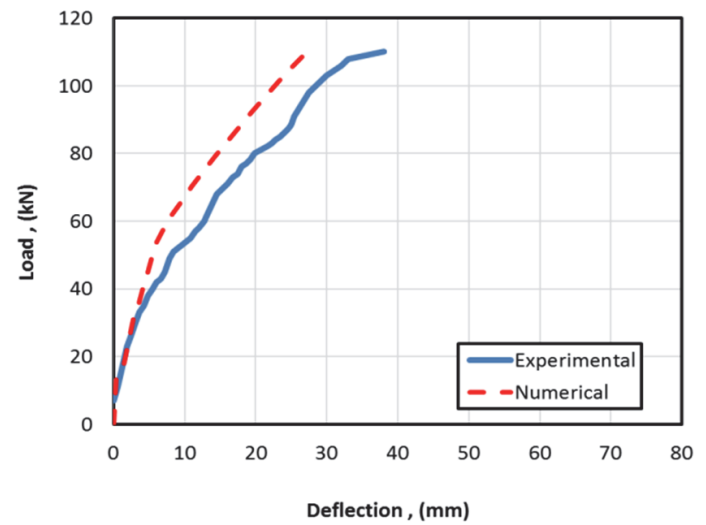

$\mathrm{B}_{1.80-\mathrm{B}}$

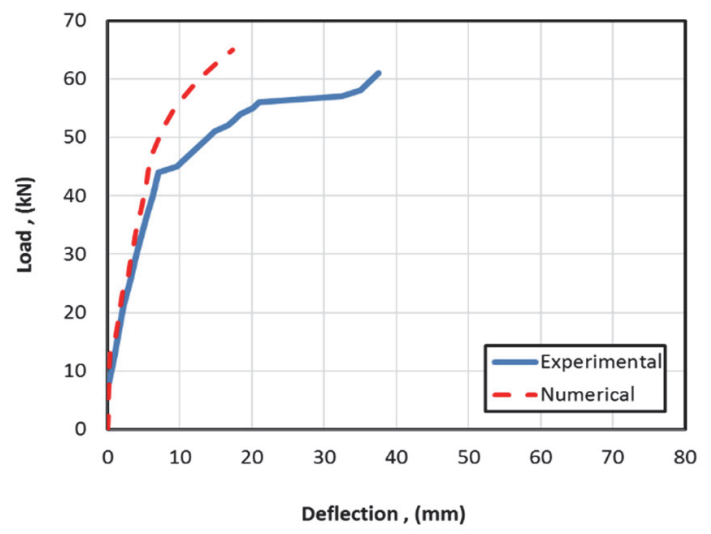

$\mathrm{B}_{1.15-\mathrm{B}}$

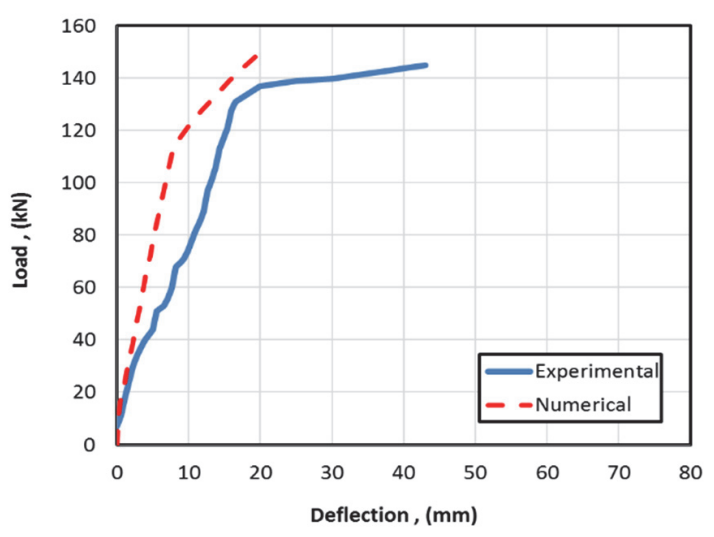

B 1.15-C

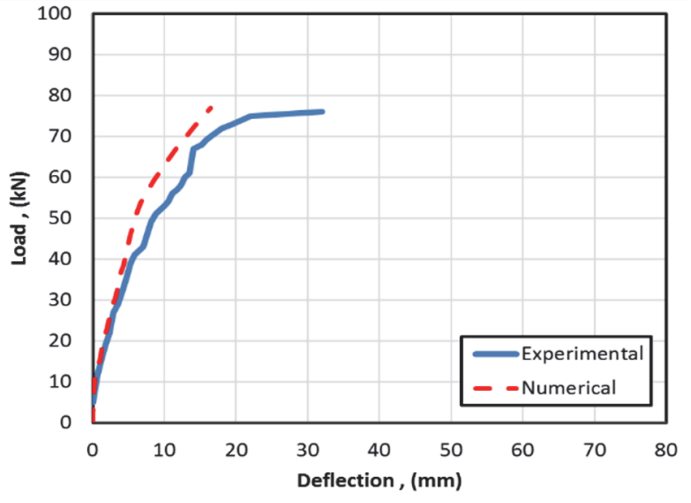

$\mathrm{B}_{1.15-\mathrm{B}}$

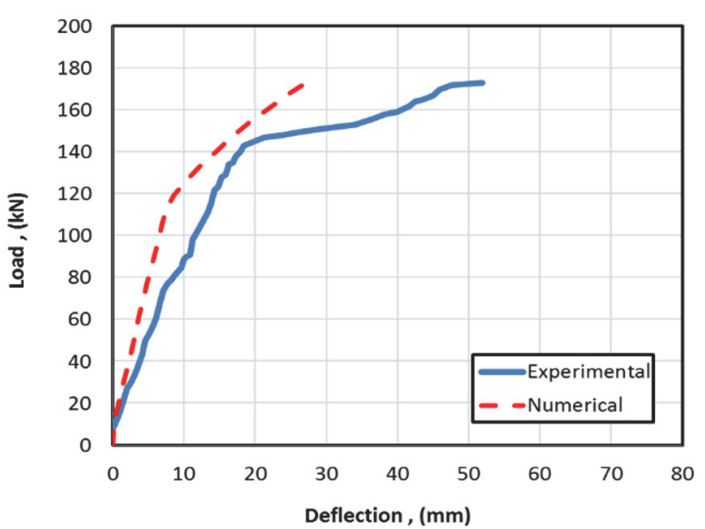

B $_{1.80-C}$

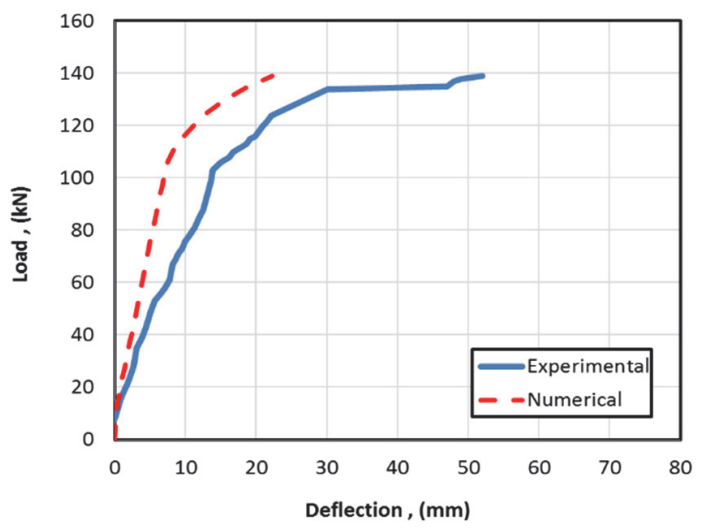

$\mathrm{B}_{0.55-\mathrm{C}}$

Figure 10: Comparison between experimental and numerical results 

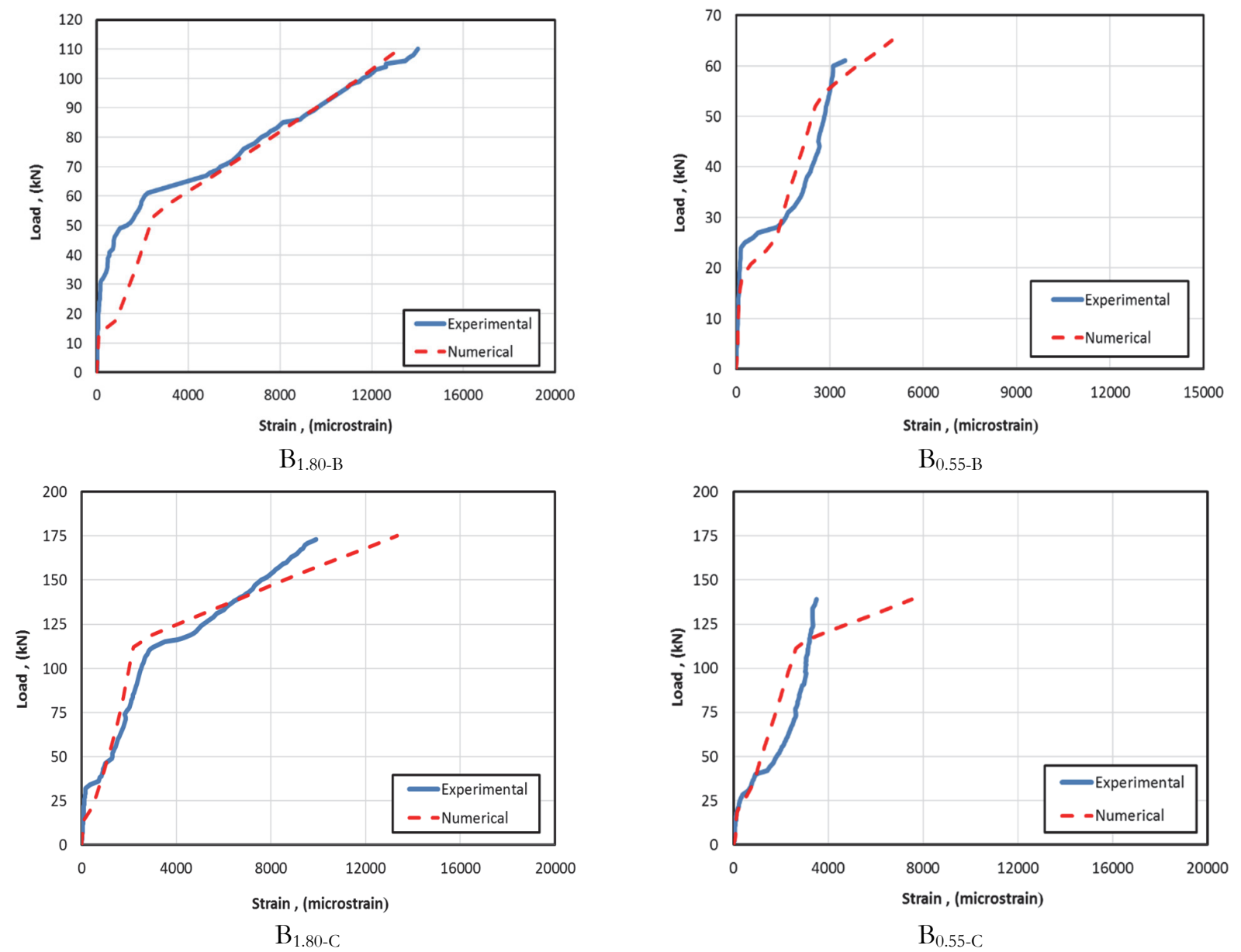

Figure 11: Comparison between the numerical and experimental strain at the mid-span of the GFRP bar

\section{CONCLUSIONS}

$\mathrm{I}$

$\mathrm{n}$ this study, the behavior of the NSM GFRP-strengthened RC beams was investigated experimentally and numerically concerning the effects of variations concrete cover, steel reinforcement ratio and lengths of NSM GFRP bars. Based on the results of this work the following conclusions could be supported:

- Decreasing the concrete cover increased the flexural capacity of the strengthened RC beams by NSM GFRP rods. This improvement disappeared by decreasing the NSM GFRP bar length.

- The strengthened beams results illustrated that RC beam flexural strength increased with increasing the main steel reinforcement ratio. Increasing tensile steel reinforcement from 2- $\varnothing 10 \mathrm{~mm}$ to $2-\varnothing 16 \mathrm{~mm}$ increased the ultimate load of the strengthened RC beams by about $57.27 \%, 90.7 \%$ and $127.8 \%$ for respectively NSM GFRP bar lengths of $1800 \mathrm{mmm}, 1150 \mathrm{~mm}$ and $550 \mathrm{~mm}$.

- Higher strain induced in NSM GFRP bars as the main tensile steel reinforcement ratio decreased and concrete cover increased.

- Strengthened beams with NSM GFRP bars length extended outside the constant moment region showed a similar mode of failure, i.e. yielding of the reinforcing steel followed by debonding and separation of the concrete cover. In the case of beams strengthened by shorter NSM GFRP rods, the crack started at the critical section (end of the GFRP rod), which is near the constant moment region and then transferred to the strengthened section.

- A 3-D FE model was developed using the commercial software ANSYS to simulate the flexural behavior of reinforced concrete beams strengthened by NSM GFRP rods. The model was able to predict the results found experimentally in an acceptable manner. 

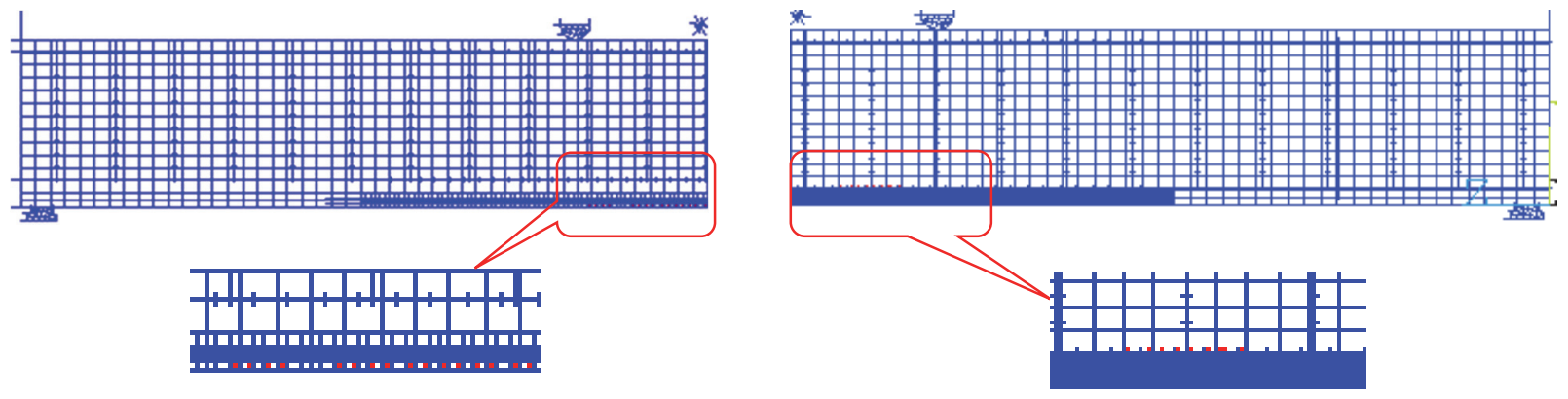

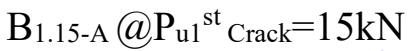
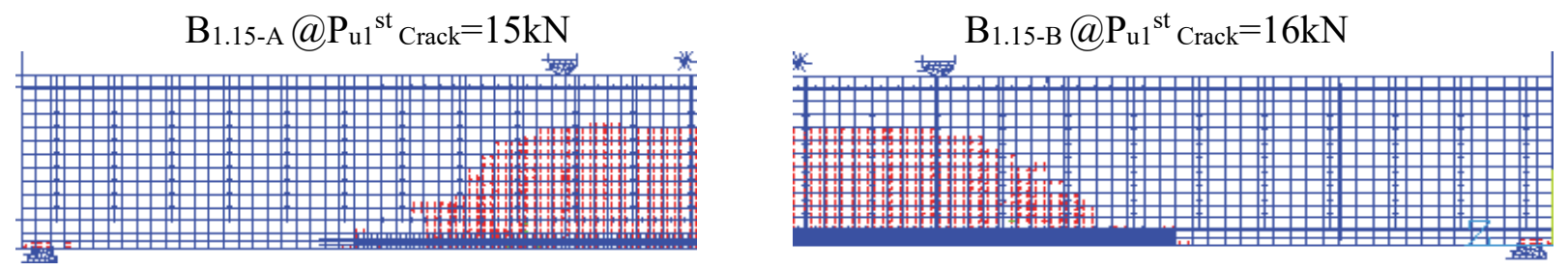

$\mathrm{B}_{1.15-\mathrm{A}} @ \mathrm{P}_{\mathrm{u}}=25.5 \mathrm{kN}$

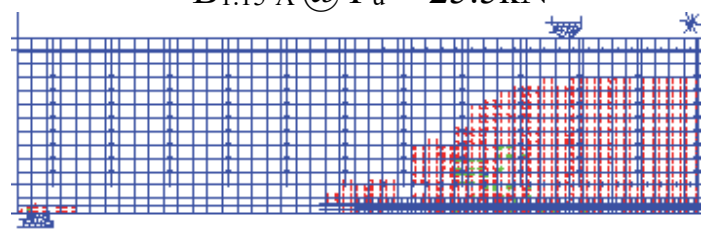

$$
\mathrm{B}_{1.15-\mathrm{B}} @ \mathrm{P}_{\mathrm{u}}=25.5 \mathrm{kN}
$$

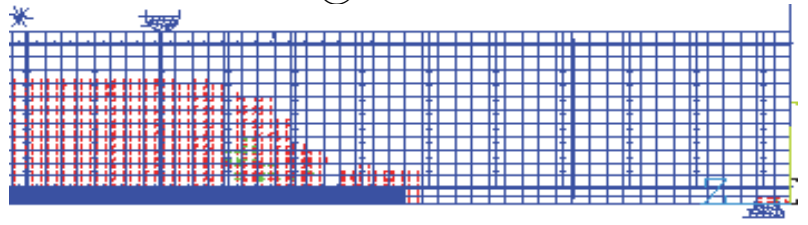

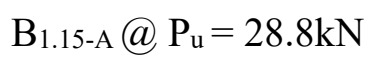

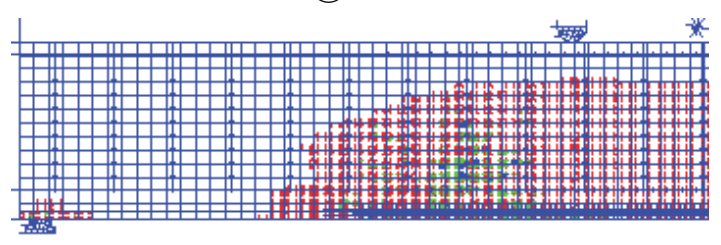

$\mathrm{B}_{1.15-\mathrm{B}} @ \mathrm{P}_{\mathrm{u}}=28.8 \mathrm{kN}$

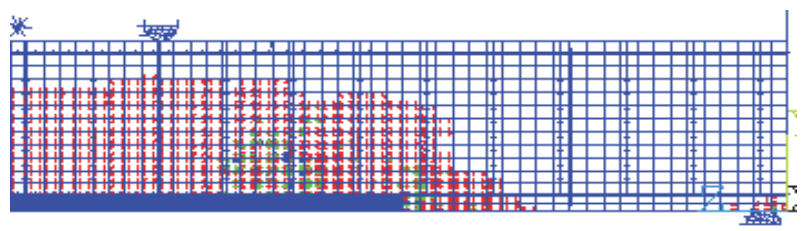

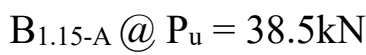

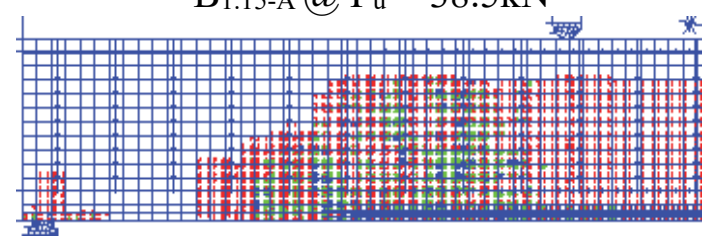

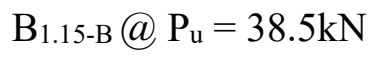

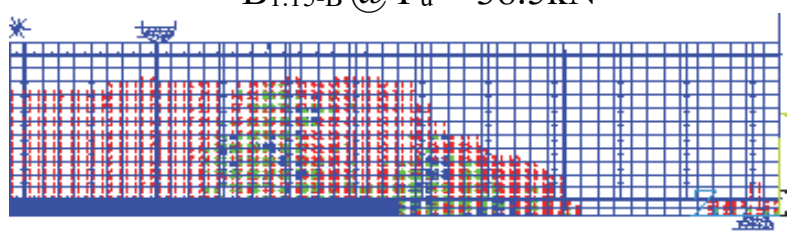

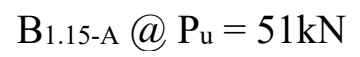

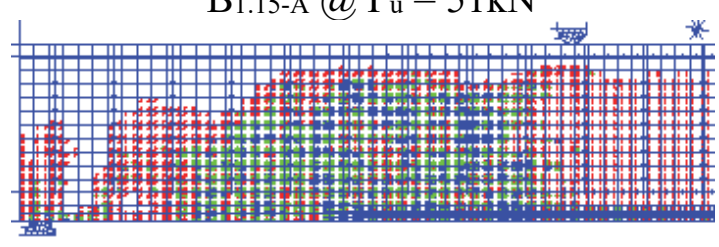

$\mathrm{B}_{1.15-\mathrm{B}} @ \mathrm{P}_{\mathrm{u}}=51 \mathrm{kN}$

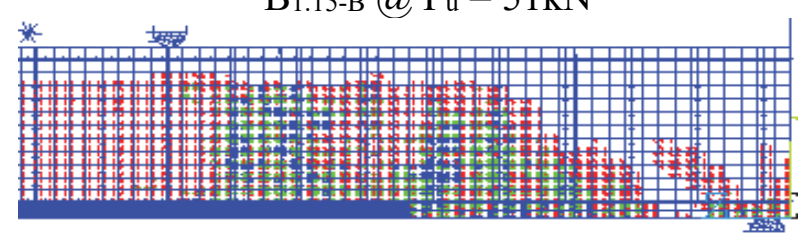
B1.15-A $@ \mathrm{Pult}_{\mathrm{u}}=72 \mathrm{kN}$
B1.15-B @ $\mathrm{Pu}_{\mathrm{u}}=72 \mathrm{kN}$

Figure 12: Comparison of a numerical crack pattern for strengthened beams with varying of concrete cover 


\section{REFERENCES}

[1] Sen, R., Liby, L. and Mullins, G. (2001). Strengthening Steel Bridge Sections Using CFRP laminates, Composites Part B, 32, pp. 309-322.

[2] Lorenzis, L.D. and Teng, J.G. (2007). Near-surface Mounted FRP Reinforcement: An Emerging Technique for Strengthening Structures, Composites Part B, 38, pp. 119-143.

[3] Wu, Z., Wang, X. and Iwashita, K. (2007). State-of-the-Art of Advanced FRP Applications in Civil Infrastructure in Japan, Composites \& Polycon, American Composites Manufacturers Association, Tampa, FL USA, pp. 1-13.

[4] Bilotta, A., Ceroni, F., Nigro, E. and Pecce, M. (2015). Efficiency of GFRP NSM strips and EBR plates for flexural strengthening of RC beams and loading pattern influence, Composites Structures, 124, pp. 163-175.

[5] Laraba, A., Merdas, A. and Chikh, N. (2014). Structural Performance of RC Beams Strengthened with NSM-CFRP, Proceedings of the World Congress on Engineering, II, pp. 958-966.

[6] Hsu, C.-T.T., Punurai, W., Bian, H. and Jia, Y. (2003). Flexural Strengthening of Reinforced Concrete Beams Using Carbon Fibre Reinforced Polymer Strips. Magazine of Concrete Research, 3, pp. 279-288.

[7] EI-Hacha, R. and Rizkalla, S.H. (2004). Near-Surface-Mounted Fiber-Reinforced Polymer Reinforcements for Flexural Strengthening of Concrete Structures, ACI Structure Journal, 101(5), pp. 717-726.

[8] Parretti, R. and Nanni, A. (2004). Strengthening of RC Members Using Near-Surface Mounted FRP Composite: Design Overview, Advances in Structural Engineering, 7(5), pp. 1-16.

[9] Yost, J.R., Gross, S.P., Dinehart, D.W. and Mildenberg, J.J. (2007). Flexural Behavior of Concrete Beams Strengthened with Near-Surface-Mounted CFRP Strips, ACI Structural Journal, 104(4), pp. 430-437.

[10] Badawi, M. and Soudki, K. (2009). Flexural Strengthening of RC beams with Prestressed NSM CFRP rodsExperimental and Analytical Investigation, Construction and Building Materials, 23(10), pp. 3292-3300.

[11] Al-Mahmoud, F., Castel, A., François, R. and Tourneur, C. (2009). Strengthening of RC Members with Near-Surface Mounted CFRP rods. Composite Structures, 91, pp. 138-147.

[12] Sun, Z.Y., Wu, G., Wu, Z.S. and Luo, Y.B. (2011). Flexural Strengthening of Concrete beams with Near-Surface Mounted Steel-Fiber Reinforced Polymer Composite bars, Journal of Reinforced Plastics and Composites, 30(18), pp. 1529-1537.

[13] Almusallam, T.H., Elsanadedy, H.M., Al-Salloum, Y.A. and Alsayed, S.H. (2013). Experimental and Numerical Investigation for the Flexural Strengthening of RC beams using Near-Surface Mounted Steel or GFRP bars, Construction and Building Materials, 40, pp. 145-161.

[14] Sharaky, I.A., Reda, R.M., Ghanem, M., Seleem, M.H. and Sallam, H.E.M. (2017). Experimental and Numerical Study of RC beams Strengthened with Bottom and Side NSM GFRP bars having Different End Conditions, Construction and Building Materials, 149, pp. 882-903.

[15] Shabana, I.S., Sharaky, I.A., Khalil, A., Hadad, H.S. and Arafa, E.M. (2018). Flexural Response Analysis of Passive and Active Near Surface - Mounted Joints: Experimental and Finite Element Analysis, Materials and Structures, 51(107), pp. 1-15.

[16] Lorenzis, L.D. and Nanni, A. (2002). Bond Between Near Surface Mounted FRP Rods and Concrete in Structural Strengthening, ACI Structures Journal, 99(2), pp. 123-133.

[17] Lorenzis, L.D. (2004). Anchorage Length of Near-Surface Mounted Fiber-Reinforced Polymer Rods for Concrete Strengthening -Analytical Modeling, ACI Structural Journal, 101(3), pp. 375-386

[18] Galati, D. and Lorenzis, L.D. (2009). Effect of Construction Details on the Bond Performance of NSM FRP Bars in Concrete, Advances in Structural Engineering, 12(5), pp. 683-700.

[19] Rahman, M.M. and Jumaat, M.Z. (2013). The Effect of CFRP Laminate Length for Strengthening the Tension Zone of the Reinforced Concrete T-Beam, Journal of Scientific Research \& Reports, 2(2), pp.626-640.

[20] Sharaky, I.A., Torres, L., Comas, J. and Barris, C. (2014). Flexural Response of Reinforced Concrete (RC) Beams Strengthened with Near Surface Mounted (NSM) Fibre Reinforced Polymer (FRP) bars, Composite Structures, 109, pp. 8-22.

[21]Zhang, S.S., Yu, T. and Chen, G.M. (2017). Reinforced Concrete beams Strengthened in Flexure with Near-Surface Mounted (NSM) CFRP Strips: Current Status and Research needs, Composites Part B, 131, pp. 30-42.

[22] Foret, G. and Limam, O. (2008). Experimental and Numerical Analysis of RC Two-Way Slab Strengthened with NSM CFRP rods, Construction and Building Materials, 22, pp. 2025-2030.

[23] Hawileh, R.A. (2012). Nonlinear Finite Element Modeling of RC Beams Strengthened with NSM FRP rods, Construction and Building Materials, 27, pp. 461-471. 
[24] Khene, A., Chikh, N. and Mesbah, H.A. (2016). Numerical Modeling of Reinforced Concrete Beam Strengthened By NSM- CFRP Technique, Intl Journal of Research in Chemical, Metallurgical and Civil Eng, 3(2), pp.1442-1450.

[25] Tjitradi, D., Eliatun, E. and Taufik, S. (2017). 3D ANSYS Numerical Modeling of Reinforced Concrete Beam Behavior under Different Collapsed Mechanisms, International Journal of Mechanics and Applications, 7(1), pp. 1423.

[26] American Concrete Institute ACI 318. (2011). Building Code Requirements for Structural Concrete (ACI318-11) and Commentary.

[27] Egyptian code of Practice for Design and Construction of Reinforced Concrete Structures. (2002). Guide for Laboratory tests on Concrete Materials.

[28] ANSYS, Inc. (2018). Release 19.0 Documentation for Ansys.

[29] Kabir, M.Z. and Omran, H.Y. (2008). Numerical and Analytical Modeling of RC Beams Strengthened in Flexure with Near Surface Mounted CFRP Strips, The $4^{\text {th }}$ National Conference on Civil Engineering, University of Tehran. 